\title{
Three New Species of Dendrogaster (Crustacea: Ascothoracida) Infecting Goniasterid Sea-Stars (Echinodermata: Asteroidea) from Japan
}

\author{
Nobuhiro Saito ${ }^{1,5}$, Kaori Wakabayashi ${ }^{2,3}$, and Takeya Moritaki ${ }^{4}$ \\ ${ }^{1}$ Suido-sha Co. Ltd., Ikuta 8-11-11, Tama-ku, Kawasaki, Kanagawa 214-0038, Japan \\ E-mail: nsaitoh@suidosha.co.jp \\ ${ }^{2}$ Graduate School of Integrated Sciences for Life, Hiroshima University, \\ Kagamiyama 1-4-4, Higashi-Hiroshima, Hiroshima 739-8528, Japan \\ ${ }^{3}$ Previous address: Graduate School of Marine Science and Technology, Tokyo University of Marine Science and Technology, \\ 4-5-7 Konan, Minato, Tokyo 108-8477, Japan \\ ${ }^{4}$ Marine Biological Laboratory, Toba Aquarium, Toba 3-3-6, Toba, Mie 517-8517, Japan \\ ${ }^{5}$ Corresponding author
}

(Received 19 March 2019; Accepted 17 December 2019)

http://zoobank.org/48A296CF-AD86-4BDA-BBE3-E874B3734F7A

\begin{abstract}
Three new species of the ascothoracidan crustacean genus Dendrogaster Knipovich, 1890 (Dendrogasteridae) are described from goniasterid sea-stars in Japan. Dendrogaster komatsuae sp. nov. and D. tobasuii sp. nov. were found respectively in the coelomic cavities of Lithosoma japonica Hayashi, 1952 and two species of Mediaster: M. arcuatus (Sladen, 1889) and M. brachiatus Goto, 1914 from the Kumano-nada Sea. Dendrogaster nagasakimaruae sp. nov. was similarly found in Nymphaster euryplax Fisher, 1913 from the East China Sea. Partial DNA sequences of the cytochrome $c$ oxidase subunit I and $16 \mathrm{~S}$ ribosomal RNA genes were determined for $D$. tobasuii sp. nov. These findings represent the first records of Dendrogaster from the host family Goniasteridae in Japan.
\end{abstract}

Key Words: Bathyal zone, DNA barcoding, East China Sea, endoparasite, Kumano-nada Sea, prevalence.

\section{Introduction}

Ascothoracida Lacaze-Duthiers, 1880 is an infraclass of the Thecostraca Gruvel, 1905 within the Crustacea Brünnich, 1772. They comprise a little more than 100 nominal species divided among six families in two orders (Grygier and Høeg 2005; Grygier 2019a). All ascothoracidans parasitize echinoderms or cnidarians (Grygier and Høeg 2005). They are basically characterized by a bivalved carapace that contains diverticula of the gut and gonads and encloses the main body. The body fundamentally consists of a cephalon with a pair of grasping antennules and an oral cone and an 11-segmented trunk with six pairs of thoracic limbs and a penis. However, most ascothoracidans are highly modified in form (Wagin 1976; Grygier and Høeg 2005).

Dendrogaster Knipovich, 1890 is one of the genera including highly modified form of ascothoracidan crustaceans. Females are endoparasitic, occurring exclusively in the coelomic cavity of sea-stars (Fig. 1). The carapace of females is modified into a dendritic mantle that resembles the gonads or pyloric caeca of the host. The mantle is usually filled with eggs or larvae. The dwarf males, on the other hand, are shaped like a pair of dividers and live within the female's mantle cavity. The segmentation and appendages of the trunk are well developed in males (Palmer 1997; Kolbasov 2007), while those are vestigial in females (Grygier
1987; Grygier and Høeg 2005). Dendrogaster comprises a total of 31 species (Grygier 2019b) recorded from sea-stars representing 13 different families (Grygier 1987, 1990; Jangoux 1987; Stone 1987; Palmer 1997). Five species have been recorded from Japanese waters: D. astropectinis (Yosii, 1931) from Astropecten scoparius Müller and Troschel, 1842

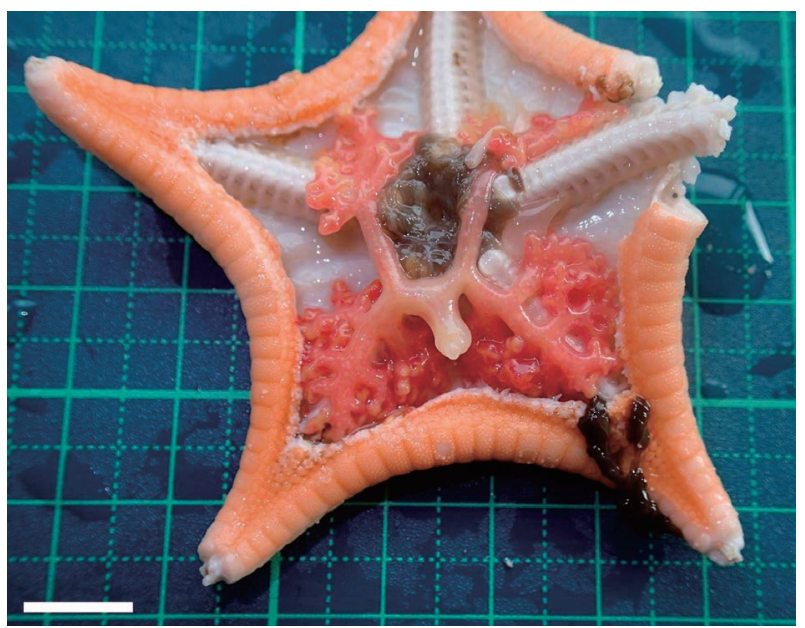

Fig. 1. Mediaster brachiatus Goto, 1914 (R $37 \mathrm{~mm}, \mathrm{r}$ unmeasured) infected with Dendrogaster tobasuii sp. nov., paratype ovigerous female, NSMT-Cr 26865, in the coelomic cavity with dorsal body wall of the sea-star removed, dorsal view. Scale bar $=10 \mathrm{~mm}$. 
and A. polyacanthus Müller and Troschel, 1842 (Astropectinidae) (e.g., Yosii 1931; Fukui Kenritsu Takefu Kôtôgakkô Seibutsubu 2002); D. okadai (Yosii, 1931) from Coscinasterias acutispina (Stimpson, 1862) (Asteriidae) (Yosii 1931; Haramoto et al. 2007); D. ludwigi Le Roi, 1905 from Certonardoa semiregularis (Müller and Troschel, 1842) (Ophidiasteridae) (Yosii 1931) and Echinaster luzonicus (Gray, 1840) (Echinasteridae) (Grygier 1996), although the accuracy of Yosii's identification is doubtful (Grygier 1996); D. rimskykorsakowi Wagin, 1950 from Ctenodiscus crispatus (Bruzelius, 1805) (Goniopectinidae) (Ito et al. 2009); and D. murmanensis Wagin, 1950 from Crossaster papposus (Linnaeus, 1767) (Solasteridae) (Ito et al. 2009). Moreover, there seems to be a few more unidentified species of Dendrogaster in the sea-stars of the families Asteriidae, Astropectinidae, and Echinasteridae according to some Japanese echinoderm researchers (e.g., Nakagawa et al. 2012).

In the present paper, we report the discoveries of three new species of Dendrogaster infecting Japanese goniasterid sea-stars. The family Goniasteridae consists of over 60 genera with over 250 species (Mah 2019), most of which inhabit the deep sea (Saba et al. 2002; Kogure 2018). Only two species of goniasterid sea-stars from North American waters have been known as hosts of Dendrogaster species: Hippasteria californica Fisher, 1905 from Gull Islet off Santa Cruz Island, California, USA, infected with $D$. arbusculus Fisher, 1911 (q.v., Grygier 1982) and H. phrygiana (Parelius, 1768) from the St Lawrence Estuary off Rimouski, Canada, infected with Dendrogaster sp. (Hamel and Mercier 1994, 1999). Here we describe the external morphology of the Dendrogaster species found in the Japanese goniasterid sea-stars. DNA barcoding was employed to determine whether the Dendrogaster females found in two congeneric sea-stars belong to the same species.

\section{Materials and Methods}

Sampling and morphological examination. The goniasterid sea-stars, Lithosoma japonica Hayashi, 1952, Mediaster arcuatus (Sladen, 1889), M. brachiatus Goto, 1914, and Nymphaster euryplax Fisher, 1913, were collected from the bathyal zone in Japanese waters. The former three species were caught in the Kumano-nada Sea, Pacific coast of central Japan, by the fishing trawlers Jinsho-maru and Kiei-maru during surveys of the Kumano-nada marine fauna carried out by the Toba Aquarium in 2014-2016. The host sea-stars were transported alive to the Toba Aquarium. Nymphaster euryplax was collected in the East China Sea by TR/V Nagasaki-maru, Nagasaki University (cruise N321) using a beam trawl and transported alive to a laboratory at Tokyo University of Marine Science and Technology. Identifications of the host sea-stars followed Goto (1914), Kogure and Moritaki (2016), and Kogure (2017).

After being dead (at the aquarium) or anesthetized by freezing (in the university laboratory), the dorsal body wall of each host sea-star was removed to check whether Dendrogaster was present in the coelomic cavity: the infection was not usually detectable by the outward appearance. Once found, the Dendrogaster specimens were isolated from their hosts, photographed, and then preserved in 70 or $100 \%$ ethanol.

Morphological characters of Dendrogaster were observed under a binocular dissecting microscope (Olympus X-II). Measurements and drawings of all appendages were made with the aid of a compound microscope (Olympus BHB-Tr) equipped with a drawing tube. Drawings of entire females were made by tracing the outline of specimens from photocopies made of them. Mantle size of the females was measured as the greatest distance across the branched mantle in outstretched condition. Other measurements and terminology for adults of Dendrogaster follow Grygier (1987), and terminology for nauplius follows Karande and Oguro (1981) and Stone (1987). Measurements of host sea-stars included their radius (R) and interradius (r) (Imaoka et al. 1990).

The examined specimens of both Dendrogaster and host sea-stars were deposited in the collections of the National Museum of Nature and Science (NSMT), Tsukuba, Japan, and at the Toba Aquarium Marine Biological Laboratory (TAMBL), Toba, Japan.

DNA analysis. Commonly used barcoding genes, mitochondrial cytochrome $c$ oxidase subunit I gene (COI) and $16 \mathrm{~S}$ ribosomal RNA gene (16S rRNA) (Hebert et al. 2003; Vogler and Monaghan 2006; Hajibabaei et al. 2007; Bucklin et al. 2011), were used for molecular comparisons among the Dendrogaster specimens found from Mediaster. Muscle tissue of the middle piece or the tips of terminal protuberances were taken from preserved specimens for extraction of genomic DNA using NucleoSpin Tissue (Lot\# 1604006M, Macherey-Nagel, Germany) following the manufacturer's protocol. The COI ( 707 bps) and 16S rRNA ( 610 bps) genes were amplified by polymerase chain reaction (PCR) using the universal primer pairs LCO1490/HCO2198 (Folmer et al. 1994) and 16Sar-L/16Sbr-H (Palumbi et al. 2002), respectively. PCR was carried out in a $50 \mu \mathrm{l}$ reaction mixture using Blend Taq plus DNA polymerase (Toyobo, Japan). The temperature regime for PCR was as follows: $10 \mathrm{~min}$ at $94^{\circ} \mathrm{C}$ for initial denaturation, 40 cycles of $1 \mathrm{~min}$ at $94^{\circ} \mathrm{C}$, $1 \mathrm{~min}$ at $50^{\circ} \mathrm{C}, 1 \mathrm{~min}$ at $72^{\circ} \mathrm{C}$, and then $10 \mathrm{~min}$ at $72^{\circ} \mathrm{C}$ for final extension. The amplified DNA fragments were purified using a QIAquick gel extraction kit (Qiagen, Germany) after electrophoresis in $1.5 \%$ agarose gel (SeaKem ME agarose, Lonza, Rockland, USA). Purified fragments were used for cycle sequencing reaction with the same primers as those used for PCR. Cycle sequencing was performed in a $10 \mu \mathrm{l}$ reaction mixture using a BigDye Terminator v3.1 Cycle Sequencing Kit (Applied Biosystems, Foster City, USA). The temperature regime for cycle sequencing was as follows: $30 \mathrm{sec}$ at $96^{\circ} \mathrm{C}, 15 \mathrm{sec}$ at $50^{\circ} \mathrm{C}$, and $4 \mathrm{~min}$ at $60^{\circ} \mathrm{C}$ for 25 cycles. Sequencing was carried out with a DNA sequencer (ABI 3130xl Genetic Analyzer, Applied Biosystems, Foster City, USA). As references partial sequences of both genes were also determined for D. okadai (NSMT-Cr 26856, GenBank Nos. MN913411 for COI and MN955444 for $16 S$ ) and D. rimskykorsakowi (NSMT-Cr 26857, GenBank Nos. MN913412 for COI and MN955445 for 16S) which 
were found in a coelomic cavity of Coscinasterias acutispina collected from the rocky shore $(0.5 \mathrm{~m})$ in Anamizu, Ishikawa Prefecture, Sea of Japan on 12 October 2004 and that of Ctenodiscus crispatus collected from Toyama Bay (300-600 m), Sea of Japan on 29 April 2006, respectively. MEGA 7 (Kumar et al. 2016) was used to clean and align the sequences, and then the nucleotide positions for analysis were selected by Gblocks 0.91b (Castresana 2000). MEGA 7 was also used to compute the genetic distances estimated by K2P model (Kimura 1980). The COI and 16S rRNA genes sequences were deposited with the International Nucleotide Sequence Database Collaboration through the National Center for Biotechnology Information.

\section{Systematic Account}

Family Dendrogasteridae Gruvel, 1905

Genus Dendrogaster Knipovich, 1890

Dendrogaster komatsuae sp. nov.

[New Japanese name: Yamatoishidatami-no-shidamushi] (Figs 2, 3)

Material examined. Holotype: ovigerous female (mantle size $46.3 \mathrm{~mm}$ ), NSMT-Cr 26858, removed on 18 October 2015 from coelomic cavity of Lithosoma japonica Hayashi, 1952 (Echinodermata: Asteroidea: Valvatida: Goniasteridae) (R 50.0 mm, r $25.3 \mathrm{~mm}$ ), TAMBL-EC10, off Owase, Kumano-nada Sea, Pacific coast of central Japan, about $300 \mathrm{~m}$ depth, by Kiei-maru on 13 January 2014.

Paratype: one ovigerous female (fragmented into main
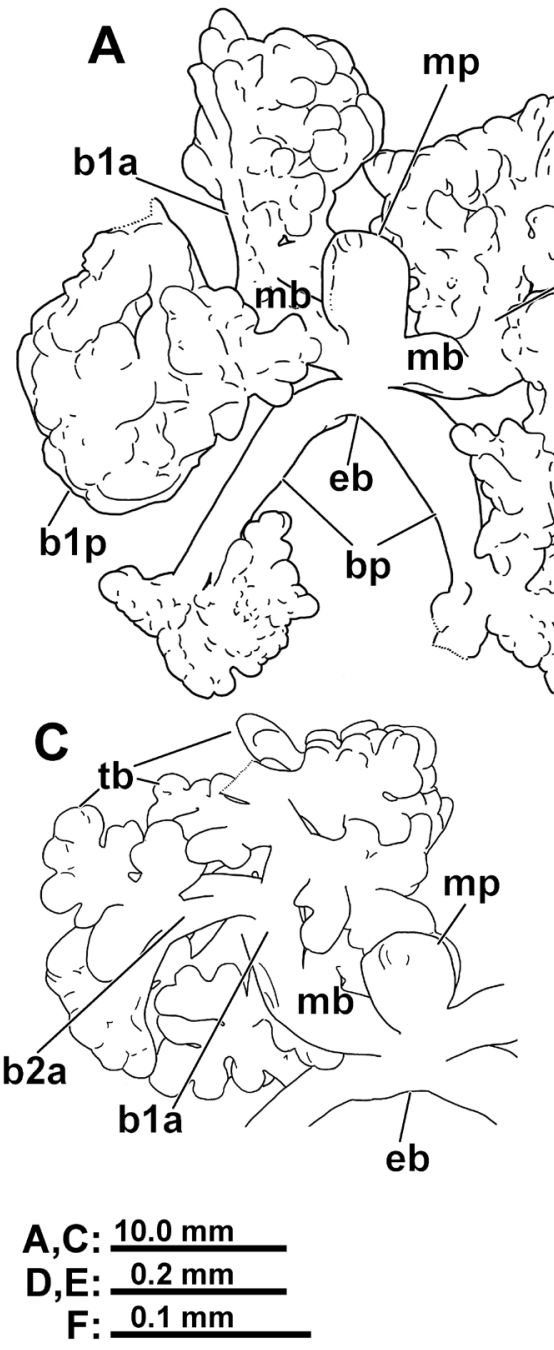

A,C: $10.0 \mathrm{~mm}$

$\mathrm{F}: 0.1 \mathrm{~mm}$
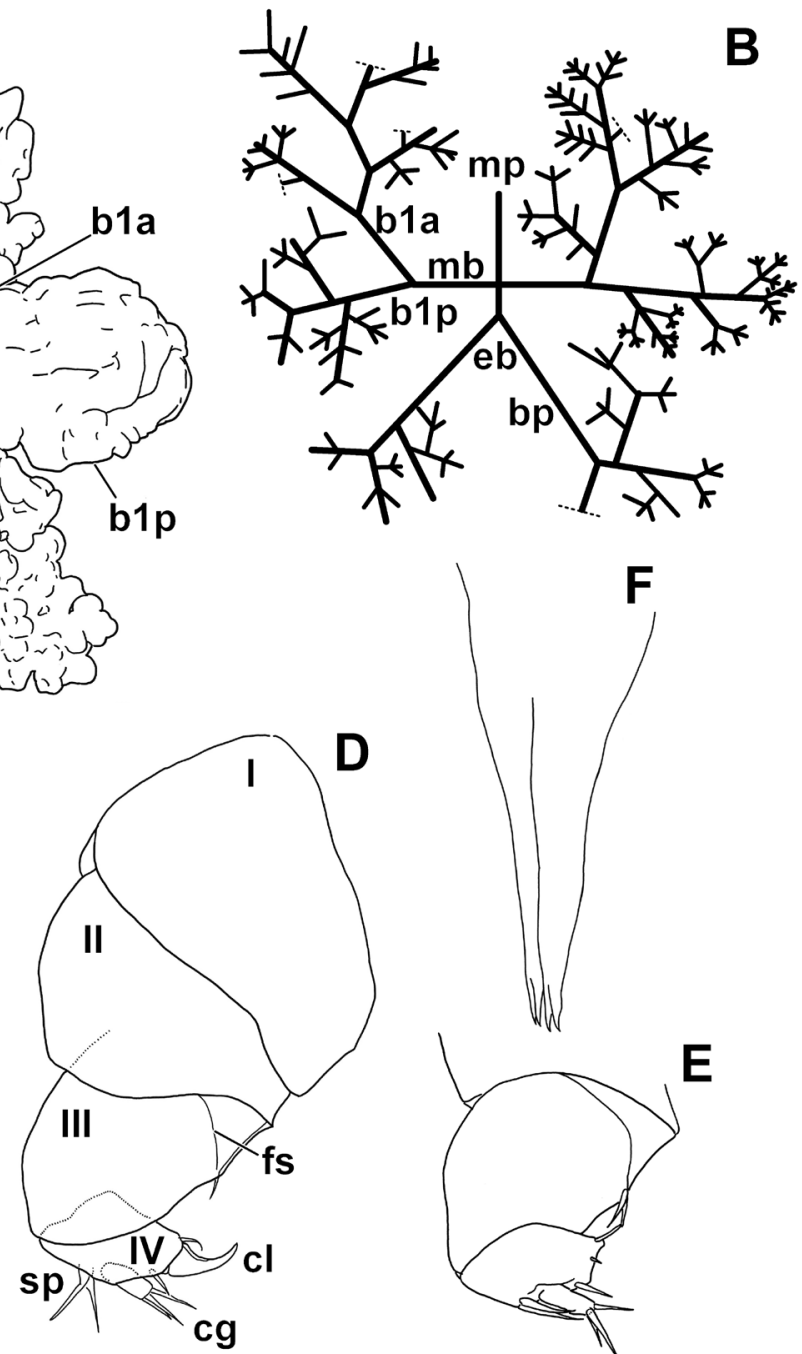

b1p

$-$
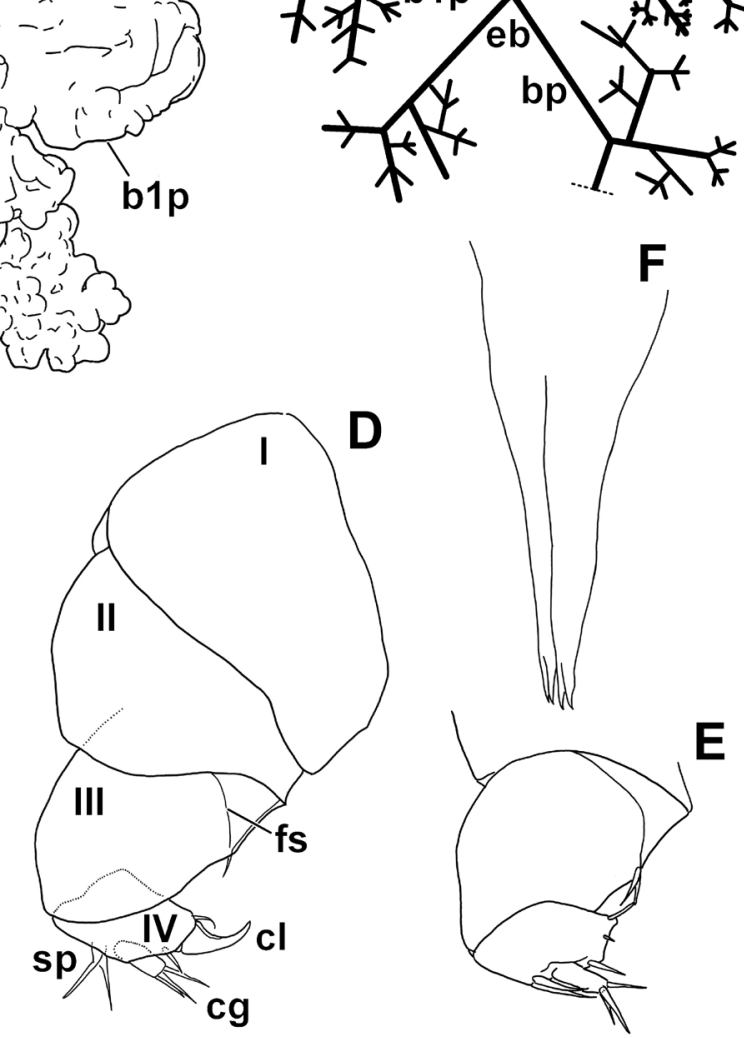

Fig. 2. Dendrogaster komatsuae sp. nov., holotype female, mantle size $46.3 \mathrm{~mm}$, NSMT-Cr 26858, removed from coelomic cavity of Lithosoma japonica (R $50.0 \mathrm{~mm}, \mathrm{r} 25.3 \mathrm{~mm}$ ), TAMBL-EC10, Kumano-nada Sea off Owase, Mie Prefecture, Pacific coast of central Japan, about $300 \mathrm{~m}$ depth. A, whole animal, dorsal view; B, linear scheme to indicate a pattern of mantle branching; C, left anterior branches, unfurled; D, left antennule, medial view; E, third and fourth segments of right antennule (terminal claw missing), lateral view; F, second maxillae. Abbreviations: b1a, anterior primary branches; b2a, anterior secondary branches; bp, posterior branches; b1p, posterior primary branches; cg, claw guard; cl, terminal claw; eb, extra branch; fs, fusion seam; I-IV, segment numbers; mb, main branches; mp, middle piece; sp, rudimentary proximal sensory process; tb, terminal branch. 
body and 3 pieces of mantle), NSMT-Cr 26859, removed from coelomic cavity of the same host specimen as holotype.

No males were found from both the holotype and paratype.

Description of holotype female. Carapace (or mantle) markedly branched, surface smooth (Fig. 2A, B): mantle cavity filled with numerous eggs and nauplius larvae. Middle piece elliptical, 1.2 times as long as wide, subequal in length to each main branch. Pair of main branches directed laterally from base of middle piece, each 1.1 times as long as wide and dividing into 2 (anterior and posterior) primary branches. Primary branches quickly subdividing into cauliflower-like masses of short branches, with terminal branches blunt and rounded (Fig. 2C). Extra branch present opposite to middle piece, immediately dividing into pair of long posterior branches with distal parts subdivided in same manner as primary branches (Fig. 2A, B).

Antennules 4-segmented and subchelate (Fig. 2D, E). Second article trapezoidal. Third article elliptical, with fusion seam crossing proximal-dorsal angle and 2 short setae at distal end of seam (broken in left antennule). Fourth article rectangular, with movable terminal claw (missing in right antennule), large, cylindrical claw guard, and rudimentary posterior sensory process; bearing 3 short setae at dorsal, ventral and lateral bases of terminal claw (maybe broken in left antennule), 3 somewhat longer distal setae on cylindrical claw guard, and 2 setae ( 1 of it surely undeveloped aesthetascs) on posterior process.

Oral cone formed by labrum ensheathing second maxillae. First maxillae and mandibles absent. Second maxillae (Fig. 2F) harpoon-like, right and left members of pair fused medially for most of length but separate at distal end; terminal prong bifid with sharp tips.

Rudiments of thoracopods absent.

Eggs present in mantle cavity spherical, $0.52 \mathrm{~mm}$ in diameter $(n=20)$.

Nauplius larvae from mantle cavity (Fig. 3) with bowlshaped carapace, oval in dorsal view, $0.83 \times 0.66 \mathrm{~mm}$ $(\mathrm{n}=20)$; antennules, antennae, mandibles, labrum, and anal spine present; frontal filaments and medial knob, nauplius eye, maxillules, thoracic appendages, caudal appendages and rami, and abdominal spines absent. Antennules uniramous with 5 indistinct segments, bearing 3 terminal, 2 medial, and 1 lateral setae. Antennae biramous; exopod with 12 indistinct segments, each of distal 5 segments bearing 1 long seta; endopod with 5 indistinct segments, 4 setae at distal end. Mandibles biramous; exopod with 13 indistinct segments, distal 5 segments bearing 1 long seta; endopod with 5 indistinct segments, 4 setae at distal end. Labrum pointed posteriorly. No ascothoracid larvae were found.

Coloration. White to cream yellow (in ethanol-preserved specimens).

Infection parameters. The single damaged host specimen examined in the present study infected with 2 females.

Etymology. Named in honor of Emeritus Professor Miéko Komatsu, University of Toyama, Japan, for her significant contributions to the knowledge of echinoderm biology.

Diagnostic remarks. The presence of a bifid branch on the mature female opposite the middle piece links Dendrogaster komatsuae sp. nov. to three other congeneric species that also possess an 'extra branch' of some kind in this location: D. arbusculus; D. dogieli Wagin, 1950 from Pteraster
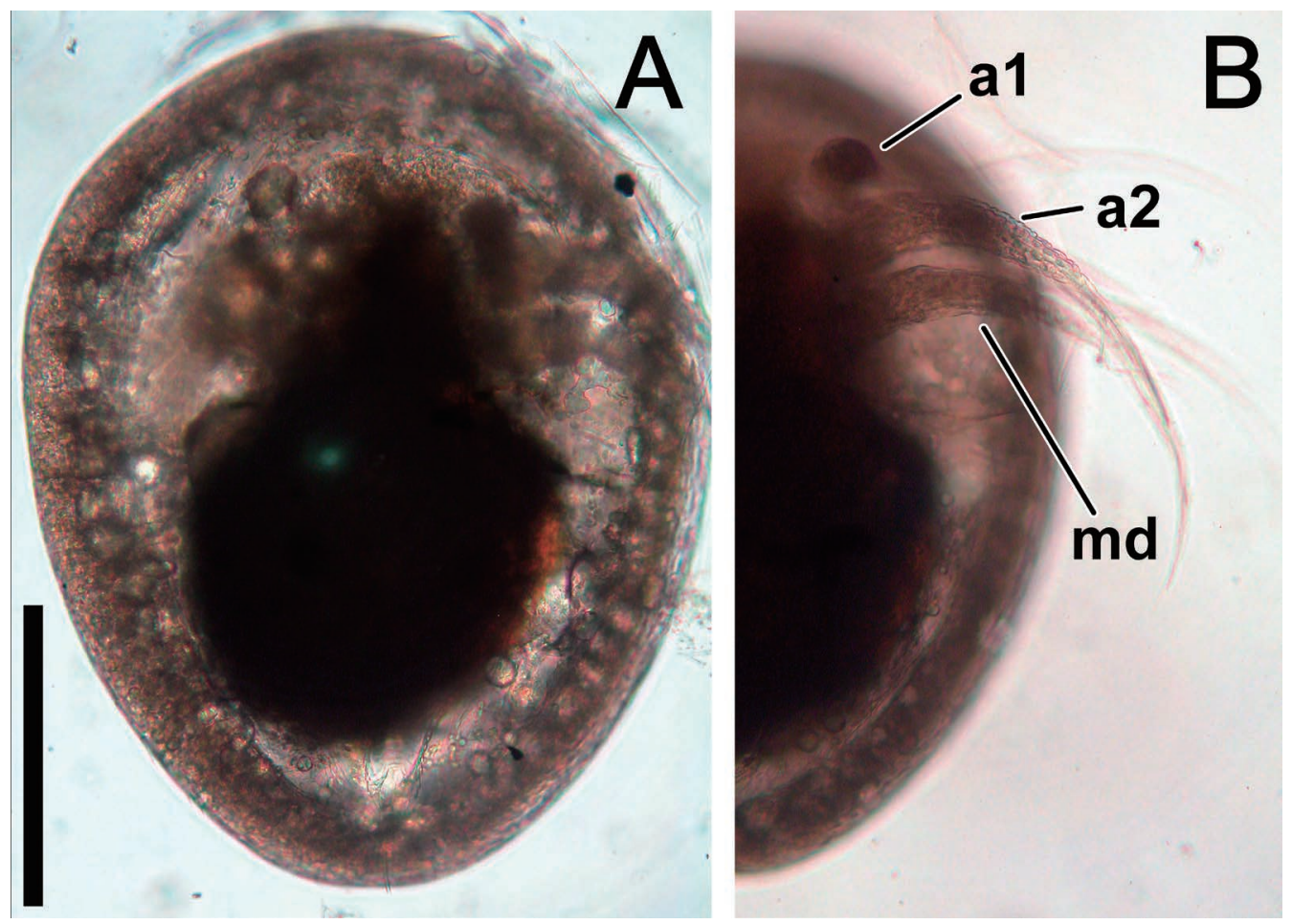

Fig. 3. Dendrogaster komatsuae sp. nov., nauplius, carapace length $0.87 \mathrm{~mm}$, from holotype female. A, whole animal, ventral view; B, left portion of body, ventral view. Abbreviations: a1, antennule; a2, antenna; $\mathrm{md}$, mandible. Scale bar $=0.3 \mathrm{~mm}$. 
obscurus (Perrier, 1891) (Pterasteridae); D. otagoensis Palmer, 1997 from Diplodontias miliaris (Gray, 1847) (Odontasteridae) (Fisher 1911; Wagin 1950, 1976; Grygier 1982; Palmer 1997). Dendrogaster komatsuae sp. nov. can be separated from $D$. otagoensis by the immediate split of the extra branch into a pair of long posterior branches; $D$. otagoensis has just an unbranched rounded knob, mistakenly referred to as the 'middle piece' by Palmer (1997). Dendrogaster komatsuae can be separated from $D$. dogieli by the ramification pattern of the rest of the mantle, namely by the presence of anterior and posterior primary branches. In the main branches of $D$. dogieli are uniaxial with a bilateral series of distally smaller and simpler secondary branches. Dendrogaster komatsuae most closely resembles the Californian species D. arbusculus (see Fisher 1911; Grygier 1982) but is distinguished from it by the number of primary branches divided from main branch (two pairs in D. komatsuae sp. nov. vs. three pairs in $D$. arbusculus), the length of the posterior branches on the extra branch (considerably longer in D. komatsuae), and the condition of the terminal branches (blunt and rounded in D. komatsuae vs. conical and scattered in D. arbusculus).

\section{Dendrogaster tobasuii sp. nov.}

[New Japanese name: Yumiherigokaku-no-shidamushi] (Figs 1, 4-6)

Material examined. Holotype: ovigerous female (mantle size $59.9 \mathrm{~mm}$, Fig. 4), NSMT-Cr 26860, removed on 31 October 2015 from coelomic cavity of Mediaster arcuatus
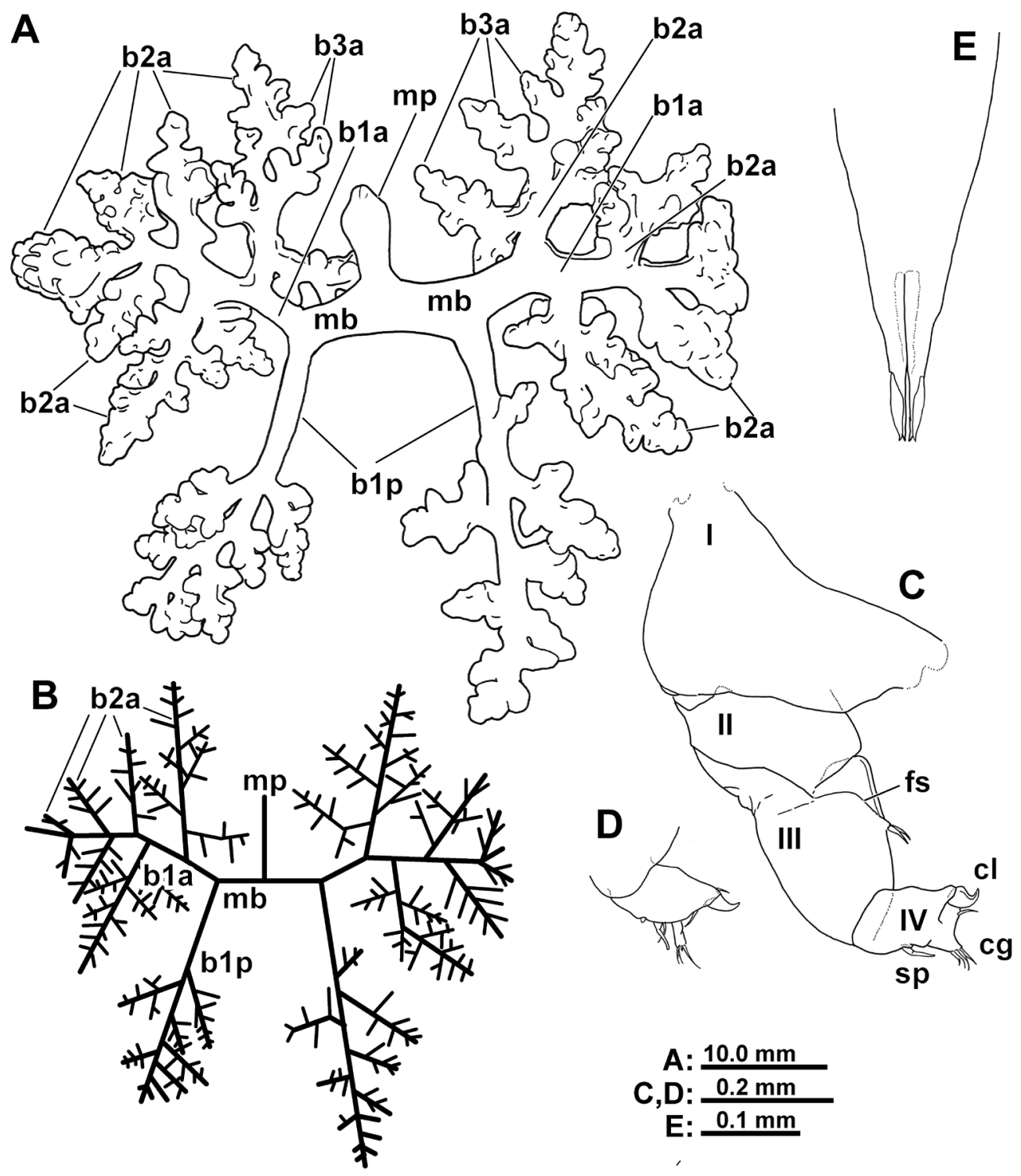

Fig. 4. Dendrogaster tobasuii sp. nov., holotype female, mantle size $59.9 \mathrm{~mm}$, NSMT-Cr 26860, removed from coelomic cavity of Mediaster arcuatus (unmeasured), Kumano-nada Sea off Owase, Mie Prefecture, Pacific coast of central Japan, about $300 \mathrm{~m}$ depth. A, whole animal, dorsal view; B, linear scheme to indicate a pattern of mantle branching; C, left antennule, medial view; D, fourth segment of right antennule, lateral view; E, second maxillae. Abbreviations: b1a, anterior primary branches; b2a, anterior secondary branches; b3a, anterior tertiary branches; blp, posterior primary branches; cg, claw guard; cl, terminal claw; fs, fusion seam; I-IV, segment numbers; mb, main branches; $\mathrm{mp}$, middle piece; sp, rudimentary proximal sensory process. 


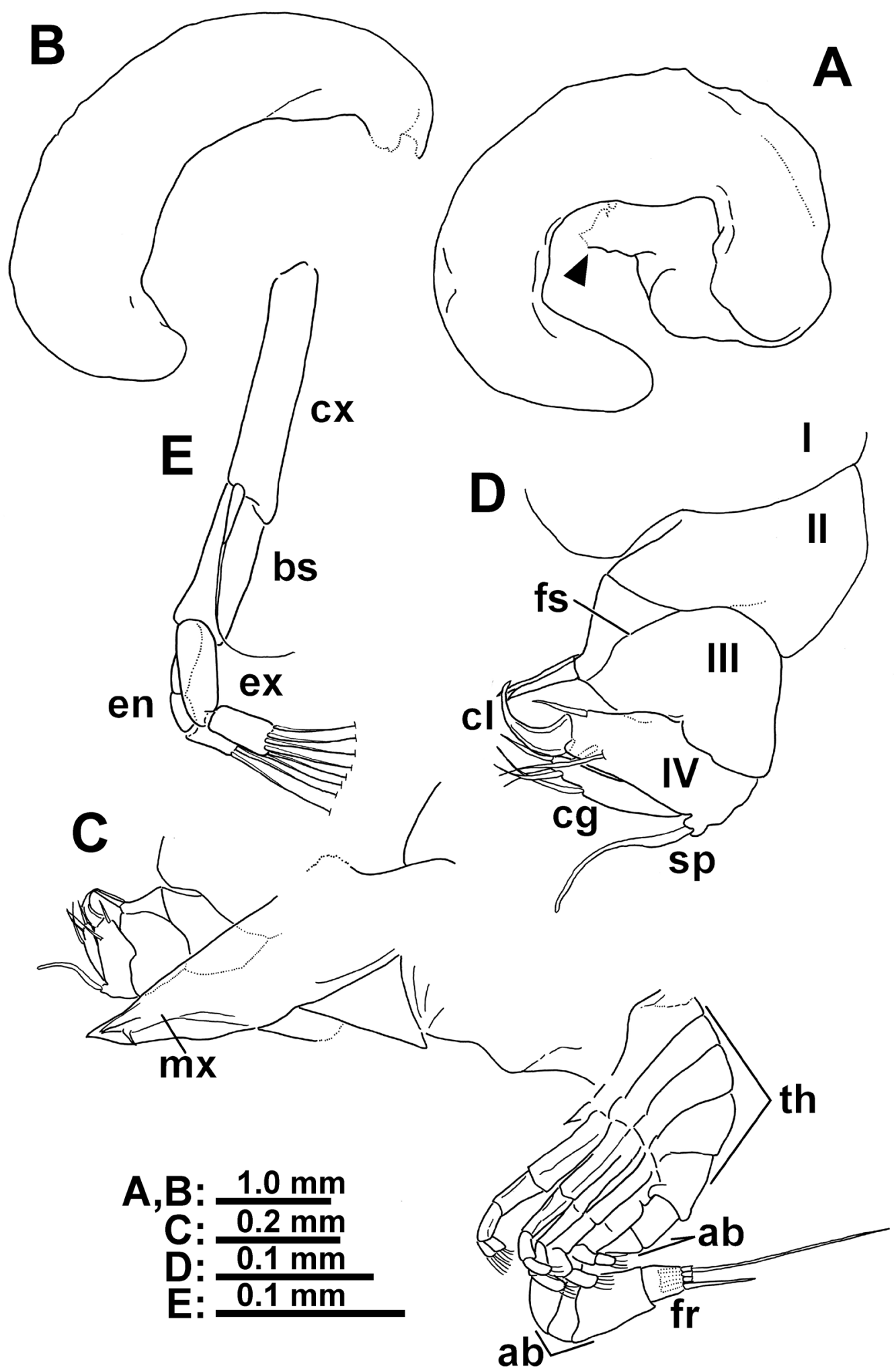

Fig. 5. Dendrogaster tobasuii sp. nov., allotype male, total length ca. $6 \mathrm{~mm}$, NSMT-Cr 26861, removed from the main branch of holotype female. A, right lateral view (arrowhead indicating point of breakage of isolated left posterior process); B, isolated left posterior process; C, main body, left lateral view (long setae of thoracic limbs and furca omitted); D, right antennule, medial view; E, left first thoracic limb (thoracopod 2), lateral view. Abbreviations: ab, abdominal segments; bs, basis; cg, claw guard; cl, terminal claw; cx, coxa; en, endopod; ex, exopod; fr, furcal rami; fs, fusion seam; I-IV, segment numbers; mx, second maxillae; sp, rudimentary proximal sensory process; th, thoracomeres.

(Sladen, 1889) (Echinodermata: Asteroidea: Valvatida: Goniasteridae) (unmeasured), Kumano-nada Sea off Mikizaki, Owase, Mie Prefecture, Pacific coast of central Japan, about
$300 \mathrm{~m}$ depth, by Kiei-maru on 29 October 2015.

Allotype: male (total length ca. $6 \mathrm{~mm}$, Fig. 5), NSMT-Cr 26861, removed from main branch of holotype female. 

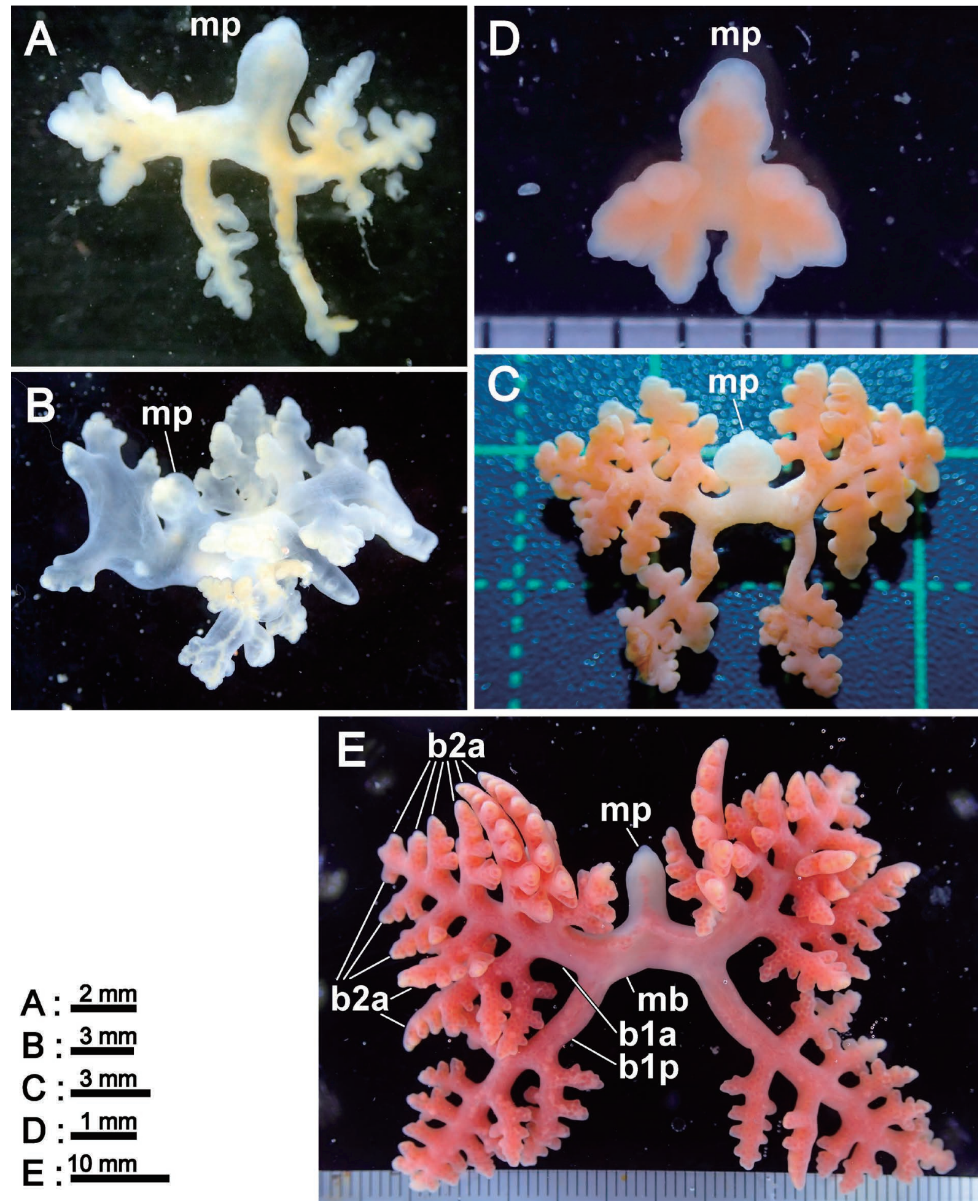

Fig. 6. Dendrogaster tobasuii sp. nov., A-B, infecting Mediaster arcuatus. A, immature female (NSMT-Cr 26862, mantle size 11.68 mm); B, transparent medium-sized female (NSMT-Cr 26870, mantle size $19.2 \mathrm{~mm}$ ). C-E, infecting M. brachiatus; C, non-ovigerous female (NSMTCr 26873, mantle size $16.0 \mathrm{~mm}$ ), middle piece tends to be expanded laterally particularly; D, immature female (NSMT-Cr 26875, mantle size $4.0 \mathrm{~mm}$ ); E, ovigerous female (NSMT-Cr 26876, mantle size $66.7 \mathrm{~mm}$ ). Abbreviations: b1a, anterior primary branches; b2a, anterior secondary branches; blp, posterior primary branches; mb, main branches; mp, middle piece.

Paratypes in coelomic cavity of $M$. arcuatus: one immature female (mantle size $11.68 \mathrm{~mm}$, Fig. 6A), NSMT-Cr 26862, removed on 12 October 2015 from damaged host, Kumano-nada Sea off Mikizaki, Owase, 200-420 m depth, coll. T. Moritaki on 29 September 2015; one juvenile (mantle size $1.39 \mathrm{~mm}$ ), NSMT-Cr 26863, removed on 13 October 2015 from host ( $23.6 \mathrm{~mm}, \mathrm{r} 12.3 \mathrm{~mm}$ ), same collection information as NSMT-Cr 26862; one female (mantle size $42.8 \mathrm{~mm}$ ), NSMT-Cr 26864, removed on 22 October 2015 from host ( $\mathrm{R} 47.0 \mathrm{~mm}, \mathrm{r} 23.4 \mathrm{~mm}$ ), same collection infor- 
mation as NSMT-Cr 26862; one ovigerous female (mantle size $49.1 \mathrm{~mm}$, Fig. 1), NSMT-Cr 26865, removed on 19 November 2015 from host ( $37 \mathrm{~mm}$, r unmeasured), same collection information as NSMT-Cr 26862; one female (mantle size $33.5 \mathrm{~mm}$ ), NSMT-Cr 26866, removed on 19 November 2015 from host (R $33 \mathrm{~mm}$, r $18 \mathrm{~mm}$ ), same collection information as NSMT-Cr 26862; one female (mantle size $33.5 \mathrm{~mm}$ ), NSMT-Cr 26867, removed on 23 January 2016 from host (R $40 \mathrm{~mm}, \mathrm{r} 24 \mathrm{~mm}$ ), Kumano-nada Sea off Mikizaki, Owase, 242-436 m depth, coll. T. Moritaki on 12 January 2016; one female (mantle size $38.8 \mathrm{~mm}$ ), NSMT-Cr 16868 , removed from the same host specimen as NSMT-Cr 26867; one non-ovigerous female (mantle size $21.8 \mathrm{~mm}$ ), NSMT-Cr 26869, removed on 29 January 2016 from host (R $35 \mathrm{~mm}$, r $13.5 \mathrm{~mm}$ ), Kumano-nada Sea off Mikizaki, Owase, $242-436 \mathrm{~m}$ depth, coll. T. Moritaki on 12 January 2016; one non-ovigerous female (mantle size $19.2 \mathrm{~mm}$, Fig. 6B), NSMT-Cr 26870, removed on 15 February 2016 from host (R $51 \mathrm{~mm}$, r $29 \mathrm{~mm}$ ), Kumano-nada Sea off Mikizaki, Owase, about $300 \mathrm{~m}$ depth, by Kiei-maru on 13 February 2016; one immature female (mantle size $9.5 \mathrm{~mm}$ ), NSMT-Cr 26871, removed on 27 February 2016 from host (R $53 \mathrm{~mm}$, r $26 \mathrm{~mm}$ ), same collection information as NSMT-Cr 26869; one female (mantle size $57.9 \mathrm{~mm}$ ), NSMT-Cr 26872, removed from the same host specimen as NSMT-Cr 26871.

Paratypes in coelomic cavity of $M$. brachiatus: one nonovigerous female (mantle size $16.0 \mathrm{~mm}$, Fig. 6C), NSMT-Cr 26873, removed on 18 January 2016 from damaged host (R unmeasured, r $10 \mathrm{~mm}$ ), Kumano-nada Sea off Mikizaki, Owase, about $300 \mathrm{~m}$ depth, coll. T. Moritaki on 12 January 2016; one ovigerous female (mantle size $21.5 \mathrm{~mm}$ ), NSMTCr 26874, removed on 29 May 2016 from damaged host (R $36 \mathrm{~mm}$, r $10 \mathrm{~mm}$ ), Kumano-nada Sea off Kii-nagashima, $300 \mathrm{~m}$ depth, coll. T. Moritaki on 29 May 2016; one immature female (mantle size $4.0 \mathrm{~mm}$, Fig. 6D), NSMT-Cr 26875 , removed on 3 June 2016 from damaged host ( $R$ $36 \mathrm{~mm}, \mathrm{r} 11 \mathrm{~mm}$ ), same collection information as NSMTCr 26874; one ovigerous female (mantle size $66.7 \mathrm{~mm}$, Fig. 6E), NSMT-Cr 26876, removed on 22 July 2016 from host (R $67 \mathrm{~mm}$, r $22 \mathrm{~mm}$ ), Kumano-nada Sea off Kii-nagashima, 200-300 m depth, coll. T. Moritaki on 26 June 2016; one male (total length $5.5 \mathrm{~mm}$ ), NSMT-Cr 26877, removed from main branch of female (NSMT-Cr 26876).

Description of holotype female. Carapace (or mantle) markedly branched, surface smooth (Fig. 4A, B): mantle cavity filled with numerous eggs. Middle piece elliptical, about twice as long as wide, 1.5 times as long as each main branch. Pair of main branches directed laterally from base of middle piece, each 1.1 times as long as wide, dividing into 2 (anterior and posterior) outspread primary branches. Each anterior primary branch giving off 3 alternately placed secondary branches on each side, these in turn giving off short tertiary branches with quaternary branches and terminal protuberances, most branches arising alternately and becoming smaller distally (first anteriorly directed secondary branch the largest). Posterior pair of primary branches elongate, extending backwards, each with 3 or 4 pairs of usually alternatively arising, rather small secondary branches on distal half, with some tertiary branches and terminal protuberances.

Antennules 4-segmented and subchelate (Fig. 4C, D). Second article rectangular. Third article elliptical, with fusion seam crossing proximal-dorsal angle and 2 stout, spiniform setae at distal end of seam. Fourth article rectangular, with movable terminal claw, large, cylindrical claw guard (irregularly in left antennule), and small vestigial proximal sensory process; bearing 2 setae at dorsal and ventral base of terminal claw (dorsal one missing in left antennule), 4 distal setae on claw guard (one of them irregularly undeveloped in left antennule), and 1 seta and 1 aesthetasc on vestigial proximal process (1 seta missing in left antennule).

Oral cone formed by labrum ensheathing second maxillae. First maxillae and mandibles absent. Second maxillae (Fig. 4E) harpoon-like, right and left members of pair fused medially for most of their length but separate at distal end; apex bifid, with distal prong and straight ventral hook reaching to tip of distal prong.

Rudiments of thoracopods absent.

Eggs present in mantle cavity semi-oval, undeveloped, $0.54 \times 0.51 \mathrm{~mm}(\mathrm{n}=20)$.

Neither nauplius nor ascothoracid larvae found in mantle cavity.

Description of allotype male. Carapace with pair of long, thick, more or less cylindrical posterior processes (Fig. 5A, B); longer left process dissected free, about 6 times as long as wide. Body composed of antennules, oral cone, 6-segmented thorax with 5 pairs of limbs on segments 2-6, and 5 -segmented abdomen terminating in pair of furcal rami (Fig. 5C).

Antennules similar to those of female (Fig. 5D): 2 long spiniform setae at distal end of seam on third article; fourth article with 3 setae, one at dorsal base of movable terminal claw and other 2 on lateral and medial side of segment; 3 setae on cylindrical claw guard; and single long aesthetasc on rudimentary proximal sensory process.

Ventral hooks of bifid second maxillae tip reflected backwards.

Thoracomeres 2 to 6 each bearing pair of biramous thoracopods with large coxa and basis, 2-segmented exopod, and 3 -segmented endopod in first 4 pairs (2-segmented in fifth pair), all limbs with 4 detail setae (Fig. 5E). Penis invisible on first abdominal segment.

In abdomen, segment 4 short, $20 \%$ as long as segment 5 (telson). Furcal rami flat and square, with 4 short distal setae on apex and 5 long medial setae.

Variation. Mantle ramification pattern of largest female paratype from M. brachiatus, NSMT-Cr 26876 (Fig. 6E), differing from that of holotype: primary branches considerably thicker in this paratype and secondary branches more numerous on both anterior and posterior primary branches, 6 or 5 pairs, respectively, vs. 3 or 4 in holotype, mostly arising alternately in holotype but in places oppositely.

Development. In immature female specimens from both host species, NSMT-Cr 26862 and 26875 (Fig. 6A, D), the middle piece about 2.5 times as long as main branch, and the secondary and tertiary branches on the two pairs of pri- 
mary branches undeveloped. Middle pieces of small female specimens from M. brachiatus, NSMT-Cr 26873 (Fig. 6C) and 26874, expanded laterally, mushroom-like, either equally wide as long or somewhat wider.

Coloration. Live immature females (NSMT-Cr 26862, Fig. 6A; 26873, Fig. 6C; and 26875, Fig. 6D) white to light yellow brown, live mature females (NSMT-Cr 26860; 26876, Fig. 6E; and 26874) pink to reddish orange. One female (NSMT-Cr 26870, Fig. 6B) transparent in life, possibly spent after spawning.

Infection parameters. Prevalence was $30.6 \%$ on Mediaster arcuatus (11/36 specimens) and $1.4 \%$ on M. brachiatus (4/280 specimens). Mediaster arcuatus and M. brachiatus were infected with 1 to 2 and 1 females, respectively.

Genetic information. Partial COI gene sequences determined from holotype (NSMT-Cr 26860, GenBank No. MN913413) and two paratypes (NSMT-Cr 26864, GenBank No. MN913414; NSMT-Cr 26870, GenBank No. MN913415) infecting Mediaster arcuatus, and two paratypes (NSMT-Cr 26873, GenBank No. MN913417; NSMTCr 26876, GenBank No. MN913416) infecting M. brachiatus being $97.4-100 \%$ identical to each other, generally implying a high possibility of conspecificity in crustaceans (Lefébure et al. 2006). In contrast, 22.4-32.4\% nucleotide differences in COI gene found between these specimens and the other two species of Dendrogaster (D. okadai and D. rimskykorsakowi). Partial 16S rRNA gene sequences determined from the holotype and two paratype specimens from $M$. arcuatus (GenBank Nos. MN955446-MN955448) being 99.1\% identical, the two paratypes from M. brachiatus (GenBank Nos. MN955449-MN955450) being 100\% identical, and the specimens from the different host sea-stars being 99.1$100 \%$ identical, also implying a high possibility of conspecificity in crustaceans (Lefébure et al. 2006). In contrast, $6.2-16.6 \%$ nucleotide differences in 16S rRNA gene found between these specimens and the other two species of Dendrogaster.

Etymology. The specific name of the new species is a Latin genitive noun, referring to the nickname "Tobasui" of the Toba Aquarium, which organized the present survey of the fauna of the Kumano-nada Sea.

Diagnostic remarks. The elongated posterior primary branches and the well-developed secondary branches on the anterior primary branches of the mantle in female Dendrogaster tobasuii sp. nov. are reminiscent of three other congeneric species, D. astropectinis, D. iwanowi Wagin, 1950 from Leptasterias fisheri Djakonov, 1929 (Asteriidae), and D. psilasteri Stone, 1987 from Psilaster andromeda (Müller and Troschel, 1842) (Astropectinidae) (Yosii 1931; Wagin 1950, 1976; Stone 1987). The new species can be differentiated from them by its smooth mantle surface ( $v s$. a mantle with prominent chitinous papillae in D. astropectinis and weak papillae in D. iwanowi) and by the number of pairs of secondary branches on each anterior primary branch (three to six in D. tobasuii vs. seven or more in D. psilasteri). In the present species, the middle piece of females tends to be expanded laterally particularly in younger specimens (NSMTCr 26873 and 26874).
Dendrogaster nagasakimaruae sp. nov.

[New Japanese name: Otohimegokaku-no-shidamushi] (Fig. 7)

Material examined. Holotype: mature female (mantle size $22.0 \mathrm{~mm}$ ), NSMT-Cr 26878, removed from a coelomic cavity of Nymphaster euryplax Fisher, 1913 (Echinodermata: Asteroidea: Valvatida: Goniasteridae) (R $60.0 \mathrm{~mm}$, r $14.6 \mathrm{~mm}$ ), East China Sea southeast of the Danjo Islands, Nagasaki Prefecture, Japan ( $\left.31^{\circ} 51.73^{\prime} \mathrm{N}, 128^{\circ} 29.13^{\prime} \mathrm{E}\right)$, 247$257 \mathrm{~m}$ depth, 6 March 2011, coll. K. Wakabayashi.

Allotype: male (total length $4.5 \mathrm{~mm}$ ), NSMT-Cr 26879, removed from main branch of holotype female.

Description of holotype female. Carapace (or mantle) markedly branched, surface smooth (Fig. 7A, B): mantle cavity filled with undeveloped eggs. Middle piece elliptical, 1.5 times as long as wide, 1.3 times as long as each main branch, and only $60 \%$ as wide basally as at point of greatest width. Pair of short, thick main branches directed laterally from base of middle piece, subequal in length to pair (anterior and posterior) of rather short, thick, widely outspread primary branches on each side. Each anterior primary branch giving rise to 2 (left) or 4 (right) secondary branches, arising alternately right sides and dichotomously on terminal of anterior primary branches. Short tertiary branches with lobe-like quaternary branches arising alternately on the second branches. Posterior primary branches extending laterally or posteriorly, 3 short secondary branches similar manner as anterior secondary branches arising alternately on each of the posterior primary branches. Ends of all branches bluntly rounded, without terminal protuberances.

Antennules 4-segmented, subchelate (Fig. 7C). Second article rectangular. Third article elliptical with curved ventral margin, fusion seam crossing proximal-dorsal angle, and 2 stout, spiniform setae at distal end of seam. Fourth article elliptical, with movable terminal claw, large, cylindrical claw guard, and rudimentary proximal sensory process; 1 seta at lateral to terminal claw, 3 distal setae on claw guard, and 2 setae ( 1 of it surely undeveloped aesthetascs) on rudimentary proximal process.

Oral cone formed by labrum ensheathing second maxillae. First maxillae and mandibles absent. Second maxillae harpoon-like (Fig. 7D), with right and left members of pair fused medially for most of length but separate distally, each with distal prong and ventral hook at apex. Distal prongs recurved laterally with medially bent tips, ventral hooks reflected backwards.

Rudimentary thoracopods absent.

Neither nauplius nor ascothoracid larvae found in mantle cavity.

Description of allotype male. Carapace (Fig. 7E) giving rise to pair of long, narrow posterior processes 6.2 times as long as wide, with lobes on basal part. Main body collapsed; abdomen and some thoracic limbs found, but antennules and oral cone missing.

Abdomen 5-segmented (Fig. 7F). Segments 1 and 2 rectangular, latter 1.5 times as long as former, penis invisible on first abdominal segment; segment 3 rectangular, subequal in 

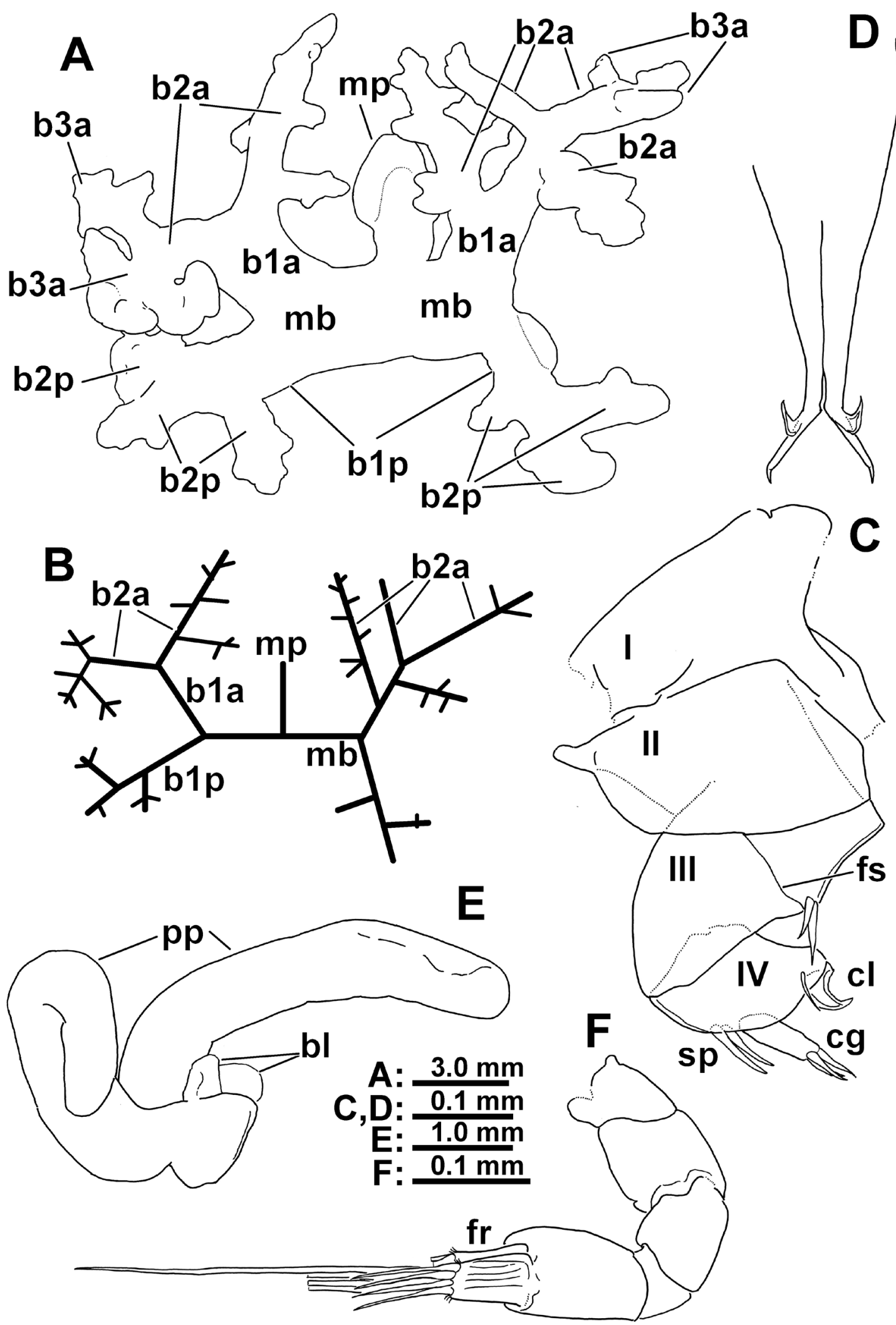

Fig. 7. Dendrogaster nagasakimaruae sp. nov., A-D, holotype female, mantle size $22.0 \mathrm{~mm}$, NSMT-Cr 26878 , removed from coelomic cavity of Nymphaster euryplax (R $60.0 \mathrm{~mm}, \mathrm{r} 14.6 \mathrm{~mm}$ ), East China Sea southeast of Danjo Islands, Nagasaki Prefecture $\left(31^{\circ} 51.73^{\prime} \mathrm{N}\right.$, $128^{\circ} 29.13^{\prime} \mathrm{E}$ ), 247-257 m depth. A, whole animal, dorsal view; B, linear scheme to indicate a pattern of mantle branching; C, left antennule, medial view; D, second maxillae, posterior view. E-F, allotype male, total length $4.5 \mathrm{~mm}$, NSMT-Cr 26879, removed from the main branch of holotype female. E, whole animal, right lateral view; F, abdomen. Abbreviations: b1a, anterior primary branches; b2a, anterior secondary branches; b3a, anterior tertiary branches; b1p, posterior primary branches; b2p, posterior secondary branches; bl, basal lobe; cg, claw guard; cl, terminal claw; fr, furcal rami; fs, fusion seam; I-IV, segment numbers; mb, main branches; mp, middle piece; pp, posterior processes; sp, rudimentary proximal sensory process. 
length to segment 1 ; segment 4 short, one quarter as long as segment 3; segment 5 rectangular, 5 times as long as segment 4.

Furcal rami square and 4 longitudinal ridges on lateral surface, with 4 short distal setae on apex and 4 long medial setae.

Coloration. Female orange in life.

Infection parameters. One of 5 individuals of Nymphaster euryplax collected off southeast of Fukue-jima, the Goto Islands (a depth of 236-237 m) in October 2010 was infected (the parasite lost). One specimen of $N$. euryplax collected in 2011 was infected with the type series. Each of those hosts infected with single female.

Etymology. The specific name is a Latin genitive noun honoring the ship TR/V Nagasaki-maru, with the feminine ending appropriate for any ship.

Remarks. Dendrogaster nagasakimaruae sp. nov. can be clearly distinguished from the other species of this genus by the unique ramification pattern of the female mantle. This features 1) short and stout main branches, 2) thick roots of the two pairs of primary branches, and 3) alternate positioning of all secondary and tertiary branches. Furthermore, the proximal basal lobes on the posterior processes of male carapace are characteristic for this new species.

\section{Discussion}

In the present paper, three new species of Dendrogaster parasitic in four species of goniasterid sea-stars are described. With these included, a total of eight species of Dendrogaster have been recorded in Japanese waters from 11 different species of sea-stars in seven families (see Introduction).

Species of Dendrogaster have successfully dispersed into diverse environments together with their host sea-stars. They are horizontally distributed from the tropical waters near the equator to the Arctic and Antarctic, and also vertically ranged from the coast to the deep-sea (Grygier 1985, 1987, 1990). This ecological and biogeographical diversity can be seen even in Japanese waters. The hosts of the eight Dendrogaster species so far recorded in Japan include tropical, temperate, and cold-water species (Saba et al. 2002; Kogure 2018). Three out of the eight Dendrogaster species (D. astropectinis, D. okadai, and D. ludwigi) infect sea-stars that inhabiting the intertidal to subtidal zone (usually up to $100 \mathrm{~m}$ in depth) (Saba et al. 2002; Kogure 2018), whereas the remaining five species, including the three new species described herein (D. murmanensis, D. rimskykorsakowi, $D$. komatsuae sp. nov., D. tobasuii sp. nov., and D. nagasakimaruae sp. nov.) infect sea-stars living in the bathyal zone (Saba et al. 1982; Ito et al. 2009; Kogure and Moritaki 2016; Kogure 2017). In fact, the two host sea-stars of the new species, Lithosoma japonica and Nymphaster euryplax, are rarely encountered bathyal species: only five (Hayashi 1952; Kogure and Moritaki 2016) and eight (Kogure 2017; present study) specimens have ever been recorded from Japan, respectively. In as much as 254 species of sea-stars are known to exist in Japanese waters (Kogure 2018), a great number of still unknown species of Dendrogaster surely remain to be discovered there.

The following nine species of goniasterid sea-stars were found in the bathyal zone of the Kumano-nada Sea during a series of faunal survey by the third author (TM): Anthenoi-

Table 1. Prevalence ratios of Dendrogaster to the sea-stars of the world based on the literature and the present study.

\begin{tabular}{|c|c|c|c|c|c|}
\hline \multirow[t]{2}{*}{ Species of Dendrogaster } & \multirow[t]{2}{*}{ Host } & \multicolumn{2}{|c|}{$\begin{array}{l}\text { Number of } \\
\text { specimens }\end{array}$} & \multirow{2}{*}{$\begin{array}{l}\text { Prevalence } \\
(\%)\end{array}$} & \multirow[t]{2}{*}{ Literature } \\
\hline & & Total & Infected & & \\
\hline \multirow[t]{2}{*}{$\begin{array}{l}\text { D. argentinensis Grygier and } \\
\text { Salvat, } 1984\end{array}$} & $\begin{array}{l}\text { Anasterias antarctica (Lütken, 1857) (Asteriidae) } \\
\quad \text { (as A. minuta) }\end{array}$ & 326 & 5 & 1.5 & Grygier and Salvat (1984) \\
\hline & Allostichaster insignis (Farquhar, 1895) (Asteriidae) & 152 & 147 & 96.7 & Palmer (1997) \\
\hline \multirow[t]{3}{*}{ D. astropectinis (Yosii, 1931) } & $\begin{array}{l}\text { Astropecten scoparius Müller and Troschel, } 1842 \\
\quad \text { (Astropectinidae) }\end{array}$ & 250 & 5 & 2.0 & Yosii (1931) \\
\hline & & 19 & 7 & 36.8 & $\begin{array}{l}\text { Fukui Kenritsu Takefu Kôtô- } \\
\text { gakkô Seibutsubu (2002) }\end{array}$ \\
\hline & $\begin{array}{l}\text { Astropecten polyacanthus Müller and Troschel, } 1842 \\
\quad \text { (Astropectinidae) }\end{array}$ & 145 & 11 & 7.6 & $\begin{array}{l}\text { Fukui Kenritsu Takefu Kôtô- } \\
\text { gakkô Seibutsubu (2002) }\end{array}$ \\
\hline D. hymenasteri Stone, 1987 & $\begin{array}{l}\text { Hymenaster pellucidus Thomson, } 1873 \text { (Pterasteridae) } \\
\quad \text { (as H. membranaceus) }\end{array}$ & 731 & 77 & 10.5 & Stone (1987) \\
\hline D. ludwigi Le Roi, 1905 & Echinaster luzonicus (Gray, 1840) (Echinasteridae) & 68 & 5 & 7.4 & Grygier (1996) \\
\hline D. nagasakimaruae sp. nov. & Nymphaster euryplax Fisher, 1913 (Goniasteridae) & 6 & 2 & 33.3 & present study \\
\hline D. otagoensis Palmer, 1997 & $\begin{array}{l}\text { Diplodontias miliaris (Gray, 1847) (Odontasteridae) } \\
\quad \text { (as Asterodon miliaris) }\end{array}$ & 159 & 124 & 78.0 & Palmer (1997) \\
\hline D. tasmaniensis Hickman, 1959 & $\begin{array}{l}\text { Allostichaster polyplax (Müller and Troschel, 1844) } \\
\quad \text { (Asteriidae) }\end{array}$ & 116 & 26 & 22.4 & Hickman (1959) \\
\hline \multirow[t]{2}{*}{ D. tobasuii sp. nov. } & Mediaster arcuatus (Sladen, 1889) (Goniasteridae) & 36 & 11 & 30.6 & present study \\
\hline & Mediaster brachiatus Goto, 1914 (Goniasteridae) & 278 & 4 & 1.4 & present study \\
\hline D. zoroasteri Stone, 1987 & $\begin{array}{l}\text { Zoroaster fulgens Wyville Thomson, } 1873 \\
\quad \text { (Zoroasteridae) }\end{array}$ & 101 & 4 & 4.0 & Stone (1987) \\
\hline Dendrogaster sp. & Hippasteria phrygia (Parelius, 1768) (Goniasteridae) & 7 & 1 & 14.3 & Hamel and Mercier (1994) \\
\hline
\end{tabular}


des epixanthus (Fisher, 1906), Hippasteria imperialis Goto, 1914, Lithosoma japonica, Mariaster giganteus (Goto, 1914), Mediaster arcuatus, M. brachiatus, Pseudarchaster parelii (Düben and Koren, 1846), Rosaster sp. 1, and Rosaster sp. 2 (Y. Kogure and T. Moritaki, unpublished). Among these seastars, seven species except the two species, $P$. parelii and Rosaster sp.1, were examined for the infection by Dendrogaster spp., but only three species explicitly noted herein as hosts of new species were infected. Hippasteria imperialis is one of the most common sea-stars in the Japanese bathyal zone (Goto 1914). In the present study, we examined 17 specimens of $H$. imperialis and found none infected with Dendrogaster, although the two congeners, $H$. californica and $H$. phrygiana, are known as hosts of two species of Dendrogaster (Grygier 1982; Hamel and Mercier 1994) and H. phrygiana is infected with Dendrogaster sp. with a prevalence of 14.3\% (Table 1, Hamel and Mercier 1994) in North American waters.

The prevalence of D. tobasuii in Mediaster arcuatus was much higher than in M. brachiatus (30.6\% vs. $1.4 \%$, respectively) even though the number of $M$. brachiatus collected was always greater than that of M. arcuatus at the surveyed sites in the Kumano-nada Sea: a few individuals of $M$. arcuatus per catch vs. 20-30 or sometimes over 100 individuals of M. brachiatus per catch (T. Moritaki, personal communications). This might suggest that $D$. tobasuii infects $M$. arcuatus selectively, at least in the area surveyed. Similarly, the prevalence of Dendrogaster astropectinis infecting seastars of Astropecten was reported as $36.8 \%$ in A. scoparius and $7.6 \%$ in A. polyacanthus, respectively in northern part of Fukui Prefecture, Japan (Fukui Kenritsu Takefu Kôtôgakkô Seibutsubu 2002). Prevalence data were reported so far for ten species of Dendrogaster (Table 1). In New Zealand, prevalence ratios of $D$. argentinensis Grygier and Salvat, 1984 (96.7\%) and D. otagoensis (78.0\%) in their respective hosts were exceptionally high (Palmer 1997), but for the other eight species the ratios were lower, ranging from $1.4 \%$ to $36.8 \%$ (Table 1). The prevalence of $D$. astropectinis was less than $2.0 \%$ in A. scoparius in the original description (Yosii 1931), much lower compared with that in the recent record in Fukui Prefecture.

\section{Acknowledgments}

We wish to express our gratitude to Dr. Jun Hashimoto, the captain and crew of the TR/V Nagasaki-maru, and the captains and crews of the fishing trawlers Jinsho-maru and Kiei-maru for their assistance in the collection of sea-stars by our project team Shida-mushi. Dr. Yoichi Kogure (Japan Sea National Fisheries Research Institute) helped us to identify sea-stars. We are grateful to Dr. Mark J. Grygier (National Taiwan Ocean University) who made helpful suggestions to a draft of this paper, and Dr. Daisuke Uyeno (Kagoshima University) and the two anonymous reviewers who provided constructive comments to the manuscript.

\section{References}

Bucklin, A., Steinke, D., and Blanco-Bercial, L. 2011. DNA barcoding of marine metazoa. Annual Review of Marine Science 3: 471-508.

Castresana, J. 2000. Selection of conserved blocks from multiple alignments for their use in phylogenetic analysis. Molecular Biology and Evolution 17: 540-552.

Fisher, W. K. 1911. Asteroidea of the North Pacific and adjacent waters. Part I. Phanerozonia and Spinulosa. Bulletin of the United States National Museum 76(1): i-iv, 1-419, pls 1-122.

Folmer, O., Black, M., Hoeh, W., Lutz, R., and Vrijenhoek, R. 1994. DNA primers for amplification of mitochondrial cytochrome $c$ oxidase subunit I from diverse metazoan invertebrates. Molecular Marine Biology and Biotechnology 3: 294-299.

Fukui Kenritsu Takefu Kôtôgakkô Seibutsubu. 2002. [On the host specificity of Dendrogaster (Crustacea)]. Umiushi Tsuushin 37: 2-3. [In Japanese]

Goto, S. 1914. A descriptive monograph of Japanese Asteroidea. 1. Archasteridæ, Benthopectinidæ, Porcellanasteridæ, Astropectinidæ, Luidiidæ, Pentagonasteridæ, Oreasteridæ, Gymnasteriidæ, Asteriidæ. Journal of the College of Science, Imperial University of Tokyo 29: 1-808, pls 1-19.

Gruvel, A. 1905. Monographie des Cirrhipèdes ou Thècostracès [Monograph of Cirrhipedia or Thecostraca]. Masson et Cie, Paris, $472 \mathrm{pp}$. [in French]

Grygier, M. J. 1982. Dendrogaster (Crustacea: Ascothoracida) from California: sea-star parasites collected by the Albatross. Proceedings of the California Academy of Sciences 42: 443-454.

Grygier, M. J. 1985. Two species of Dendrogaster (Crustacea: Ascothoracida) parasitic in porcellanasterid starfishes. Galathea Report 16: 113-120.

Grygier, M. J. 1987. Antarctic records of asteroid-infesting Ascothoracida (Crustacea), including a new genus of Ctenosculidae. Proceedings of the Biological Society of Washington 100: 700-712.

Grygier, M. J. 1990. Five new species of bathyal Atlantic Ascothoracida (Crustacea: Maxillopoda) from the equator to $50^{\circ} \mathrm{N}$ latitude. Bulletin of Marine Science 46: 655-676.

Grygier, M. J. 1996. A world list of coral reef-associated Ascothoracida (Crustacea), with remarks on Lauridae, Petrarcidae, and Dendrogastridae from Okinawa, Japan. Galaxea 13: 15-33.

Grygier, M. J. 2019a. World Ascothoracida Database. Ascothoracida. Accessed through World Register of Marine Species at: http:// www.marinespecies.org/aphia.php? $\mathrm{p}=$ taxdetails\&id $=22559 \quad(18$ March 2019).

Grygier, M. J. 2019b. World Ascothoracida Database. Dendrogaster Knipovich, 1890. Accessed through World Register of Marine Species at: http://www.marinespecies.org/aphia. php? $=$ taxdetails\&id $=103957$ (18 March 2019).

Grygier, M. J. and Høeg, J. T. 2005. Ascothoracida (ascothoracids). Pp. 149-154. In: Klaus, R. (Ed.), Marine Parasitology. CSIRO Publishing, Collingwood, Australia and CABI Publishing, Wallingford, U.K.

Grygier, M. J. and Salvat, M. B. 1984. Dendrogaster argentinensis, new species, a South American sea-star parasite (Crustacea: Ascothoracida). Proceedings of the Biological Society of Washington 97: 43-48.

Hajibabaei, M., Singer, G. A. C., Hebert, P. D. N., and Hickey, D. A. 2007. DNA barcoding: how it complements taxonomy, molecular phylogenetics and population genetics. Trends in Genetics 23: $167-172$.

Hamel, J.-F. and Mercier, A. 1994. New distribution and host record for the starfish parasite Dendrogaster (Crustacea: Ascothoracida). Journal of the Marine Biological Association of the United King- 
dom 74: 419-425.

Hamel, J.-F. and Mercier, A. 1999. Dendrogaster. Autopsie d'un parasite peu commun. Le Naturaliste Canadien 123 (hiver 1999): 55-57.

Haramoto, S., Komatsu, M., and Yamazaki, Y. 2007. Patterns of asexual reproduction in the fissiparous seastar Coscinasterias acutispina (Asteroidea: Echinodermata) in Japan. Zoological Science 24: 1075-1081.

Hayashi, R. 1952. Sea-stars of Seto and adjacent waters. Publications of the Seto Marine Biological Laboratory 2: 143-159.

Hebert, P. D. N., Ratnasingham, S., and de Waard, J. R. 2003. Barcoding animal life: cytochrome $c$ oxidase subunit 1 divergences among closely related species. Proceedings of the Royal Society of London B 270: S96-99.

Hickman, J. L. 1959. Dendrogaster tasmaniensis sp. nov. (Ascothoracida) from the sea-star Allostichaster polyplax (Müller and Troschel). Parasitology 49: 316-329.

Imaoka, T., Irimura, S., Okutani, T., Oguro, C., Oji, T., Shigei, M., and Horikawa, H. 1990. Echinoderms from Continental Shelf and Slope around Japan Vol. 1-Fiscal 1989 Project Entrusted by the Fisheries Agency of Japan -. Japan Fisheries Resource Conservation Association, Tokyo, 159 pp. [Parallel texts in Japanese and English]

Ito, T., Funatsu, H., Komatsu, M., and Grygier, M. J. 2009. [Identification and larval development of two species of Dendrogaster parasitic in seastars]. P. 33. In: [ $45^{\text {th }}$ Meeting of the Japanese Society of Systematic Zoology, Abstracts of Presentations]. [In Japanese]

Jangoux, M. 1987. Diseases of Echinodermata. III. Agents metazoans (Annelida to Pisces). Diseases of Aquatic Organism 3: 59-83.

Karande, A. A. and Oguro, C. 1981. Larvae of Myriocladus astropectinis (Yosii 1931) (Ascothoracica) reared under laboratory conditions. Proceedings of the Indian Academy of Sciences (Animal Sciences) 90: 23-31.

Kimura, M. 1980. A simple method for estimating evolutionary rates of base substitutions through comparative studies of nucleotide sequences. Journal of Molecular Evolution 16: 111-120.

Knipovich, N. 1890. [Dendrogaster astericola nov. g. et sp., new form of parasitic Cirripedia from group Ascothoracida]. Vestnik Yestestvoznaniya 1: 353-357. [In Russian]

Kogure, Y. 2017. First record of goniasterid sea stars (Echinodermata, Asteroidea, Valvatida) collected off the Goto Islands, Japan. Bulletin of the Biogeographical Society of Japan 71: 237-242. [In Japanese with English abstract]

Kogure, Y. 2018. A checklist of sea stars (Echinodermata, Asteroidea) from Japanese waters. Bulletin of the Biogeographical Society of Japan 73: 70-86. [In Japanese with English abstract]

Kogure, Y. and Moritaki, T. 2016. Rediscovery of a rarely encountered sea star, Lithosoma japonica (Echinodermata, Aseroidea, Goniastridae), from southeastern Japan. Biogeography 18: 17-22.
Kolbasov, G. A. 2007. The external morphology of parasitic crustaceans of the genus Dendrogaster (Thecostraca, Ascothoracida). Zoologicheskiy Zhurnal 86: 654-670. [In Russian with English abstract]

Kumar, S., Stecher, G., and Tamura, K. 2016. MEGA 7: Molecular Evolutionary Genetics Analysis version 7.0 for bigger datasets. Molecular Biology and Evolution 33: 1870-1874.

Lefébure, T., Douady, C. J., Gouy, M., and Gibert, J. 2006. Relationship between morphological taxonomy and molecular divergence within Crustacea: Proposal of a molecular threshold to help species delimitation. Molecular Phylogenetics and Evolution 40: 435447.

Mah, C. L. 2019. World Asteroidea Database. Goniasteridae Forbes, 1841. Accessed through: World Register of Marine Species at: http://www.marinespecies.org/aphia.php? $\mathrm{p}=$ taxdetails\&id $=$ 123135 (18 March 2019).

Nakagawa, E., Saga, M., Ito, N., Takata, K., Miyakoshi, K., Yoshimura, K., Shimizu, Y., and Hashimoto, T. 2012. [Gene analysis pertaining to the co-evolution between sea-stars and Dendrogaster]. P. 46. In: [Abstracts of the Meeting of the Chubu Branch of the Zoological Society of Japan, 2012]. [In Japanese]

Palmer, P. L. 1997. A new species of ascothoracid parasite (Maxillopoda) from the Otago Shelf, New Zealand, and a new host record. Crustaceana 70: 769-779.

Palumbi, S., Martin, A., Romano, S., McMillan, W. O., Stice, L., and Grabowski, G. 2002. The Simple Fool's Guide to PCR. University of Hawaii, Honolulu, 45 pp.

Saba, M., Irimura, S., and Soyama, I. 2002. Sea Stars and Brittle Stars in Japanese Waters. TBS Britannica, Tokyo, 135 pp. [In Japanese]

Saba, M., Tomida, Y., and Kimoto, T. 1982. Echinoderms fauna of Ise Bay, and the northern and the middle parts of Kumano-nada. Bulletin of the Mie Prefectural Museum 4: 1-82. [In Japanese]

Stone, C. J. 1987. Four new species of Dendrogaster (Ascothoracida: Maxillopoda) from the north-east Atlantic, with a note on the zoogeography of the family Dendrogastridae. Journal of Natural History 21: 1035-1048.

Vogler, A. P. and Monaghan, M. T. 2006. Recent advances in DNA taxonomy. Journal of Zoological Systematics and Evolutionary Research 45: 1-10.

Wagin, V. L. 1950. [On new parasitic crustaceans of the family Dendrogasteridae (order Ascothoracida)]. Trudy Leningradskogo Obshchestva Estestvoispytateley 70(4): 3-89. [In Russian]

Wagin, V. L. 1976. Meshkogrudye Raki [Ascothoracida]. Kazan University Press, Kazan, USSR, 141 pp. [In Russian]

Yosii, N. 1931. Note on Myriocladus. Journal of the Faculty of Science, Imperial University of Tokyo, Section IV (Zoology) 2: 237-349. 